MINERALOGIA, 42, No 1: 19-32 (2011)

DOI: 10.2478/v10002-011-0003-X

www.Mineralogia.pl

MineRALOGICAL SOCIETY OF PolAND

POLSKIE TOWARZYSTWO MINERALOGICZNE

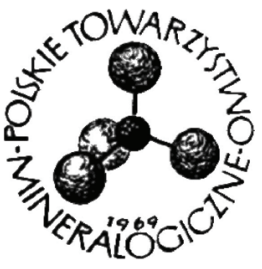

Original paper

\title{
Geochemical features of fossil fuel contaminants found in urban wastes (Siemianowice Śląskie, Poland)
}

\author{
Anna WOJTOŃ ${ }^{1}$, Monika FABIAŃSKA ${ }^{1 *}$ \\ ${ }^{1}$ University of Silesia, Faculty of Earth Sciences, 60 Będzińska Street, 42-700 Sosnowiec, Poland; \\ e-mail:monika.fabianska@us.edu.pl \\ * Corresponding author
}

Received: October 30, 2010

Received in revised form: July13, 2011

Accepted: March 10, 2012

Available online: March 28, 2012

\begin{abstract}
In sludge samples collected in the "Centrum" wastewater treatment plant in Siemianowice Śląskie, Poland, the composition of aliphatic- and aromatic hydrocarbons and polar compound fractions were investigated by gas chromatography-mass spectrometry (GC-MS). Samples collected in accordance with Polish standards were extracted, the extracts were separated into fractions with preparative thin layer chromatography (TLC), which next were investigated by GC-MS. The following compound groups of the geochemical origin were identified: $n$-alkanes in the range of $n$ - $\mathrm{C}_{14}$ to $n$ - $\mathrm{C}_{39}$, acyclic isoprenoids (mainly pristane and phytane), steranes, tri- and pentacyclic triterpanes. Based on the distribution of biomarkers and their parameters, it was established that the dominant component of extractable organic matter in sluge is petroleum material of an unspecified origin. Its geochemical features indicate that its most likely source was crude oil (or its products) of a relatively high degree of thermal maturity (catagenic stage of thermal evolution corresponding to vitrinite reflectance $0.7-0.8 \%$ ). Aromatic hydrocarbons probably originated from petroleum also, though some of them can be attributed to the products of combustion or to sources such as bituminous coals, the ash from coal/biofuel combustion or coal wastes stored nearby.
\end{abstract}

Key-words: fossil fuel biomarkers, gas chromatography-mass spectrometry, wastewater treatment 


\section{Introduction}

The progress of civilization and industrial activity leads to substantial increases in volumes of industrial and municipal waste. This creates serious social and environmental problems associated with the many adverse effects of waste on the environment. Therefore, various methods of effective waste management are needed. Wastewaters are liquids, solutions, colloids or suspensions, and solids discharged by pipelines into natural receivers, which may be reservoirs or watercourses, ditches, etc. Mechanical, chemical, and biological methods are used to purify industrial and domestic wastes discharged in this way.

Mechanical methods involve the removal of coarse organic- and mineral suspensions and floating bodies with gratings, filters, grit, grease and settlers of various types (Pawlaczyk-Szpilowa 1980). Biochemical processes and physical treatment (in part) of sewage can contribute to a further reduction in the load of organic substances. These are generally used at a further stage of purification if the methods applied previously do not provide the appropriate class of clean water for discharge to the receivers. Biological treatment takes place under both aerobic- and anaerobic conditions. It consists of oxidation and mineralization of organic compounds with micro- and macro organisms that consume compounds contained in wastewater (Hartmann 1996). The next stage of wastewater treatment is the removal of biogenic substances. Nitrogen compounds are nitrified and denitrified biologically, while phosphorus compounds are precipitated to prevent eutrophication of receivers (Miksch, Sikora 2010). However, water purified in this way retains refractory wastes and exhibits high salinity. Residual organic impurities remaining after chemical precipitation and filtration are removed by adsorption onto activated carbon or by ozone oxidation. At the last stage of water renewal, the wastes acquire the character of natural waters, thanks to which they are applicable in industry. Restoration of water allows reuse of wastewater, an important element in water resources management, especially in water-deficiency areas (Kowal 1997).

Research on organic compounds present in urban sludge has been carried out in many places all over the world, e.g. by Berset and Holzer (1999), Stevens et al. (2003), Durand et al. (2004) with the results reviewed by, e.g. Marchal et al. (2003) and Eriksson et al. (2008). In most cases, gas chromatography-mass spectrometry (GC-MS) and high pressure liquid chromaptography (HPLC) methods were applied and compounds found comprised lipids, various fragrances used as detergent components and cosmetics, pharmaceutics, and aliphatic- and polyaromatic hydrocarbons. Particular attention has been given to the latter compounds due to their carcinogenic- and mutagenic properties (e.g. Berset, Holzer 1999; Bodzek, Janoszka 1999; Stevens et al. 2003).

\section{Materials and methods}

\subsection{Characteristics of the sewage}

The wastewater treatment plant "Centrum" is located between the Siemianowice Trench and the Brynica River. Domestic and industrial wastes collected gravitationally from the settlements of Siemianowice Śląskie, Czeladź, Chorzów (Maciejkowice), Katowice (Dąbrówka Mała), Sosnowiec (Milowice) and the western part of Będzin are purified at this 
plant. The existing sewage treatment system mostly encompasses technological works designed for the mechanical and biological treatment of wastewater with a target throughput of $241,805 \mathrm{~m}^{3} /$ day.

\subsection{Samples description}

Thirteen samples of sludge collected in accordance with Polish standards (Polski Komitet Normalizacyjny 1988) at the "Centrum" plant were used for the chemical analyses. The material came from the press, sludge recirculation pumps, open fermentation basins, anaerobic sedimentation chambers, thickened sludge pump and the sludge aeration chambers (Table 1).

\subsection{Experimental section}

\subsubsection{Solvent extraction and preparative thin layer chromatography (TLC)}

Samples were extracted with dichloromethane (DCM) for 8 hours in a Soxhlet apparatus to colorless eluates (controlled with UV light). All samples were dried out prior to extraction. Preparative thin layer chromatography (TLC) was used for appraisal of the extract group compositions. Aliphatic, aromatic hydrocarbons and polar-compound fractions were separated. Extract solutions in DCM were applied as bands onto purified- and activated $20 \mathrm{x}$ $20 \mathrm{~cm}$ semi-preparative glass plates pre-coated with silica gel $60 \mathrm{~F}_{254}$ (Merck). The plates used for analyses were activated initially at $105^{\circ} \mathrm{C}$ for $45 \mathrm{~min}$. Plates were developed in a TLC tank (50 minuts in a saturated vapour condition) with $n$-heptane as an eluent. The fractions were differentiated by fluorescence of aliphatic- (lack of fluorescence) and aromatic bands (blue-violet) in long-wave UV light and by comparison with reference compounds ( $n$-eicosane, phenanthrene and isoquinoline) developed on the same plate. The recovered fractions were eluted from silica gel in short glass columns with DCM (aliphatic and aromatic compounds) or with a mixture of DCM: methanol = 4:1 (vol:vol - polar compounds).

\subsubsection{Gas chromatography-mass spectrometry (GC-MS)}

GC-MS analyses were performed using a gas chromatograph Agilent Technologies 5890 II equipped with a capillary column HP-5, length $=60 \mathrm{~m}$, internal diameter of 0.20 $\mathrm{mm}$ and stationary phase film thickness $0.25 \mu \mathrm{m}$. The gas chromatograph was directly coupled with a mass detector HP 5971 working under EI (Electron Impact), $70 \mathrm{eV}$ and scanning from 50 to 650 daltons. The experimental conditions were as follows: carrier gas - He; temperature $-50^{\circ} \mathrm{C}$ (isothermal for $2 \mathrm{~min}$ ); heating rate - up to $175^{\circ} \mathrm{C}$ at $10^{\circ} \mathrm{C} / \mathrm{min}$, to $225^{\circ} \mathrm{C}$ at $6^{\circ} \mathrm{C}$ and, finally to $300^{\circ} \mathrm{C}$ at $4^{\circ} \mathrm{C} / \mathrm{min}$. The final temperature $\left(300^{\circ} \mathrm{C}\right)$ was held for $20 \mathrm{~min}$. The results, the total ion chromatograms (TIC) and the ion chromatograms, were recorded in the full-scan mode and developed using the MS Data Analysis software (Hewlett-Packard). The results were compared with literature data, previous analyses of standard compounds and with typical distributions of compounds groups published in the geochemical literature (Wiley 2000; Peters et al. 2005). Geochemical parameters were calculated using peak areas acquired in the manual- integration mode. 


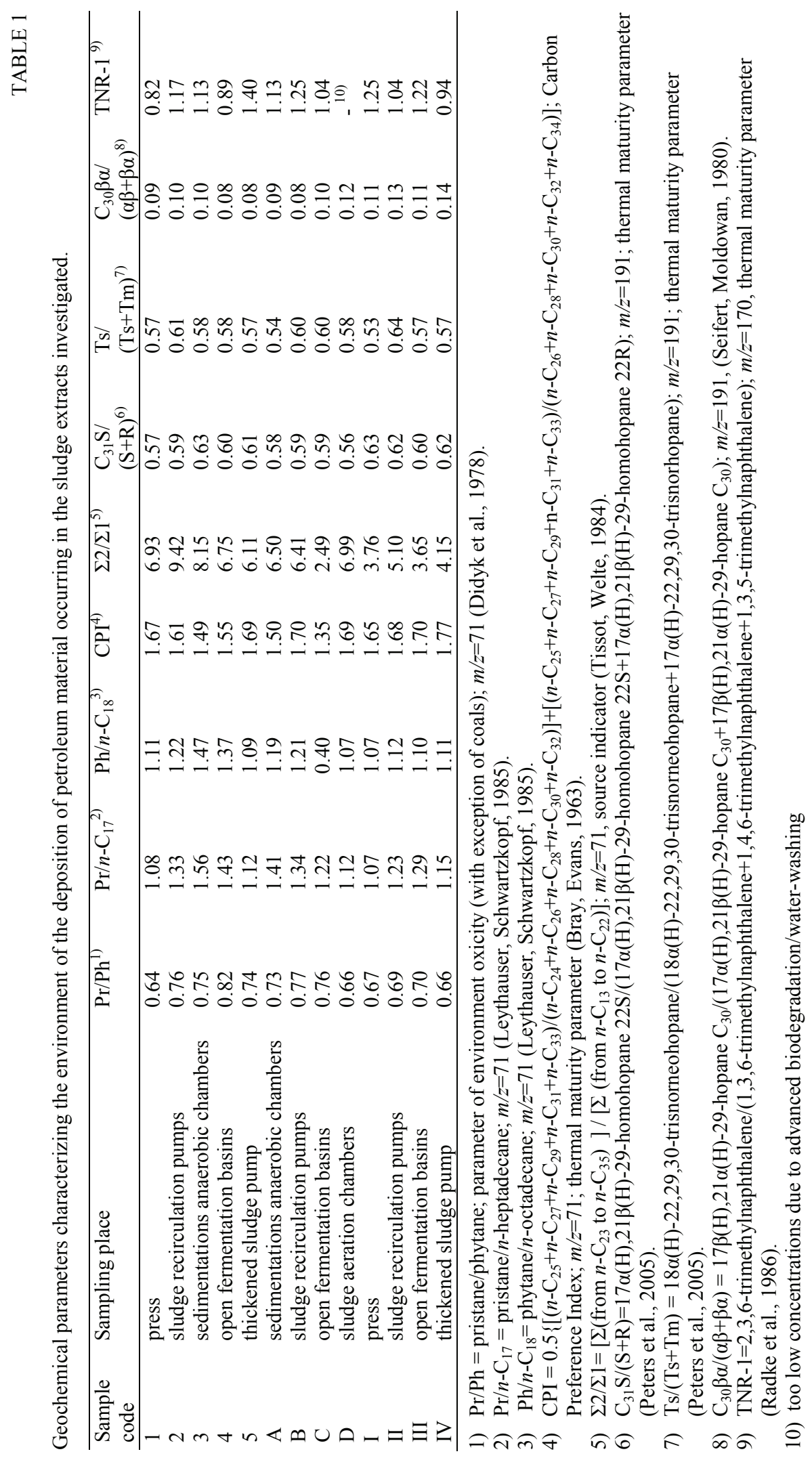




\section{Results}

\subsection{Main compound groups occurring in the sludge extracts}

In the sludge extracts, the following compound groups of geochemical origin were identified: $n$-alkanes in the range from $n$ - $\mathrm{C}_{14}$ to $n$ - $\mathrm{C}_{39}$, acyclic isoprenoids (mainly pristane and phytane, also 2,6,10-trimethylpentadecane in some samples), steranes, tri- and pentacyclic triterpanes, saturated and unsaturated fatty acids with one double bond, and their esters, alkylbenzenes and polycyclic aromatic hydrocarbons (PAHs).

\subsection{1. n-Alkanes}

In all sample extracts $n$-alkanes $(m / z=71)$ dominated comprising compounds ranging from $n-\mathrm{C}_{14}$ to $n-\mathrm{C}_{39}$. In all samples their distributions were similar, i.e. biomodal with two maxima for $n-\mathrm{C}_{17}-n-\mathrm{C}_{18}$ and around $n-\mathrm{C}_{29}$. The predominance of odd-carbon-number $n$-alkanes was clearly seen in the range from $n$ - $\mathrm{C}_{25}$ to $n$ - $\mathrm{C}_{33}$ compounds. Lighter $n$-alkanes, i.e. in the range from $n-\mathrm{C}_{14}$ to $n$ - $\mathrm{C}_{17}$ showed the outline indicating the partial removal of these compounds (Fig. 1). The ratio of a sum of long-chain $\left(n-\mathrm{C}_{23}-n-\mathrm{C}_{35}\right)$ to short chain $n$-alkanes $\left(n-\mathrm{C}_{13}-n-\mathrm{C}_{22}\right)$, with values from $2.49-9.42$, reflects the predominance of longchain compounds $(\Sigma 2 / \Sigma 1$; Table 1$)$.

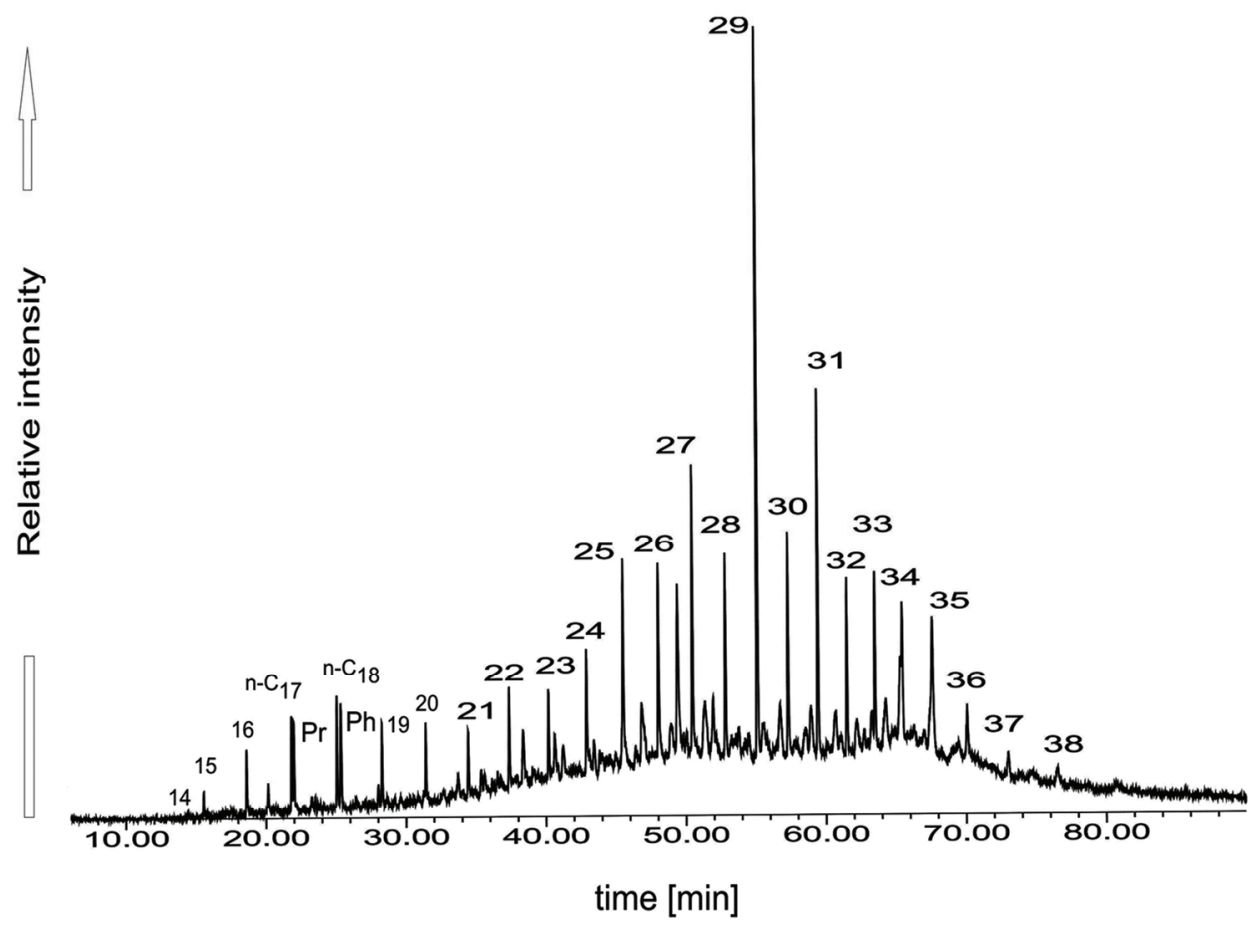

Fig. 1. Distribution of $n$-alkanes in the extract from the sludge sample $1(\mathrm{~m} / \mathrm{z}=71)$; $\mathrm{Pr}$ - pristane, $\mathrm{Ph}$ - phytane, number indicates number of carbon atoms in an $n$-alkane molecule. 


\subsubsection{Steranes}

Steranes $(m / z=217)$ occur in much smaller abundances than $n$-alkanes. Distributions of steranes include the compounds from 27 (cholestanes) to 29 (stigmastanes) carbon atoms in their molecules, and $\mathrm{C}_{30}$ steranes (24-n-propyl-cholestanes) as minor components. Stigmastane and cholestane diastereomers occur in the highest contents, with the ergostane group $\left(\mathrm{C}_{28}\right)$ present in much lower amounts. $\mathrm{C}_{30}$ steranes showed the lowest contents in all samples (Fig. 2). The sterane distribution type is almost the same in all sludge extracts.

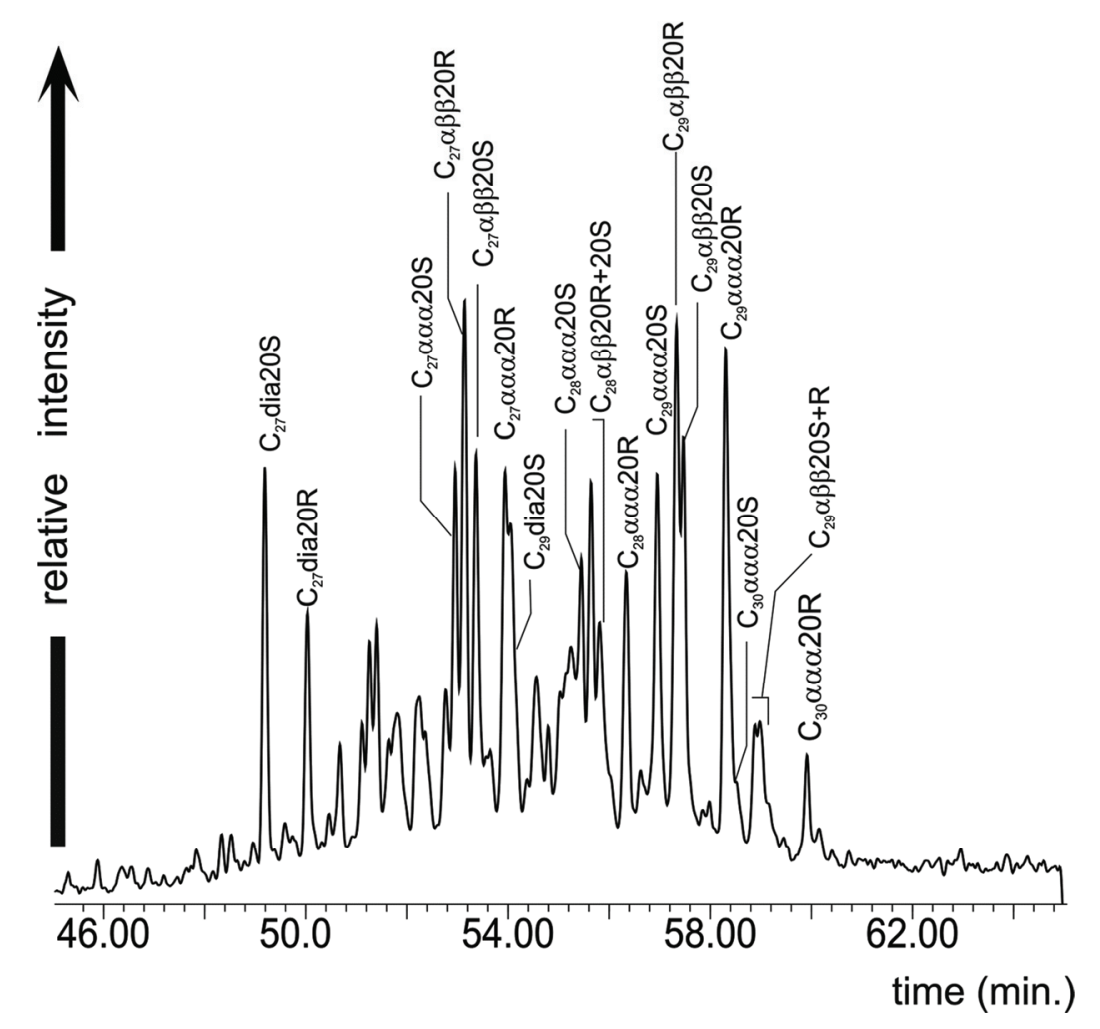

Fig. 2. Distribution of steranes $(m / z=217)$ in the extract from the sludge sample $3 ; \mathrm{C}_{27} \alpha \alpha \alpha-$ $5 \alpha, 14 \alpha, 17 \alpha(\mathrm{H})$-cholestane, $\mathrm{C}_{27} \alpha \beta \beta-5 \alpha, 14 \beta, 17 \beta(\mathrm{H})$-cholestane, $\mathrm{C}_{28} \alpha \alpha \alpha-5 \alpha, 14 \alpha, 17 \alpha(\mathrm{H})$ ergostane, $\mathrm{C}_{28} \alpha \beta \beta-5 \alpha, 14 \beta, 17 \beta(\mathrm{H})$-ergostane, $\mathrm{C}_{29} \alpha \alpha \alpha-5 \alpha, 14 \alpha, 17 \alpha(\mathrm{H})$-stigmastane, $\mathrm{C}_{29} \alpha \beta \beta-$ $5 \alpha, 14 \beta, 17 \beta(\mathrm{H})$-stigmastane.

\subsubsection{Triterpanes}

The triterpanes group $(m / z=191)$, including tricyclic- and pentacyclic triterpanes (hopanes and moretanes), occur in the extracts in much lower amounts than $n$-alkanes. Tricyclic triterpanes comprise compounds from 21-27 carbon atoms in thei molecules, with the largest relative concentration shown by $\mathrm{C}_{24}$ and two diastereomers of $\mathrm{C}_{26}$ and $\mathrm{C}_{27}$ compounds. Pentacyclic triterpanes, including compounds from $18 \alpha(\mathrm{H}) 22,29,30$ - 
trisnorneohopane (abbrev. as Ts) to $17 \alpha(\mathrm{H}) 22 \beta(\mathrm{H})$ pentakishopane (abbrev. as $\mathrm{C}_{35} \alpha \beta$ hopane), are present in higher amounts than tricyclic triterpanes. In all extracts, $17 \alpha(\mathrm{H}), 21 \beta(\mathrm{H})$-29-hopane (abbrev. as $\mathrm{C}_{30} \alpha \beta$ hopane) shows the highest amounts, and contents of $\mathrm{C}_{35} \alpha \beta$ hopane diastereomers were the lowest. Contents of moretanes $(17 \beta(\mathrm{H})$, $21 \alpha(\mathrm{H})-29$ hopanes) were relatively low compared to $\alpha \beta$ diastereomers. $17 \beta(\mathrm{H}), 21 \beta(\mathrm{H})$ hopanes (abbrev. as $\beta \beta$ hopanes) with the biological configuration of bacteriohopanetetrol, their bacterial precursor, were not identified in the extracts. The typical distribution of pentacyclic triterpanes is shown in Figure 3.

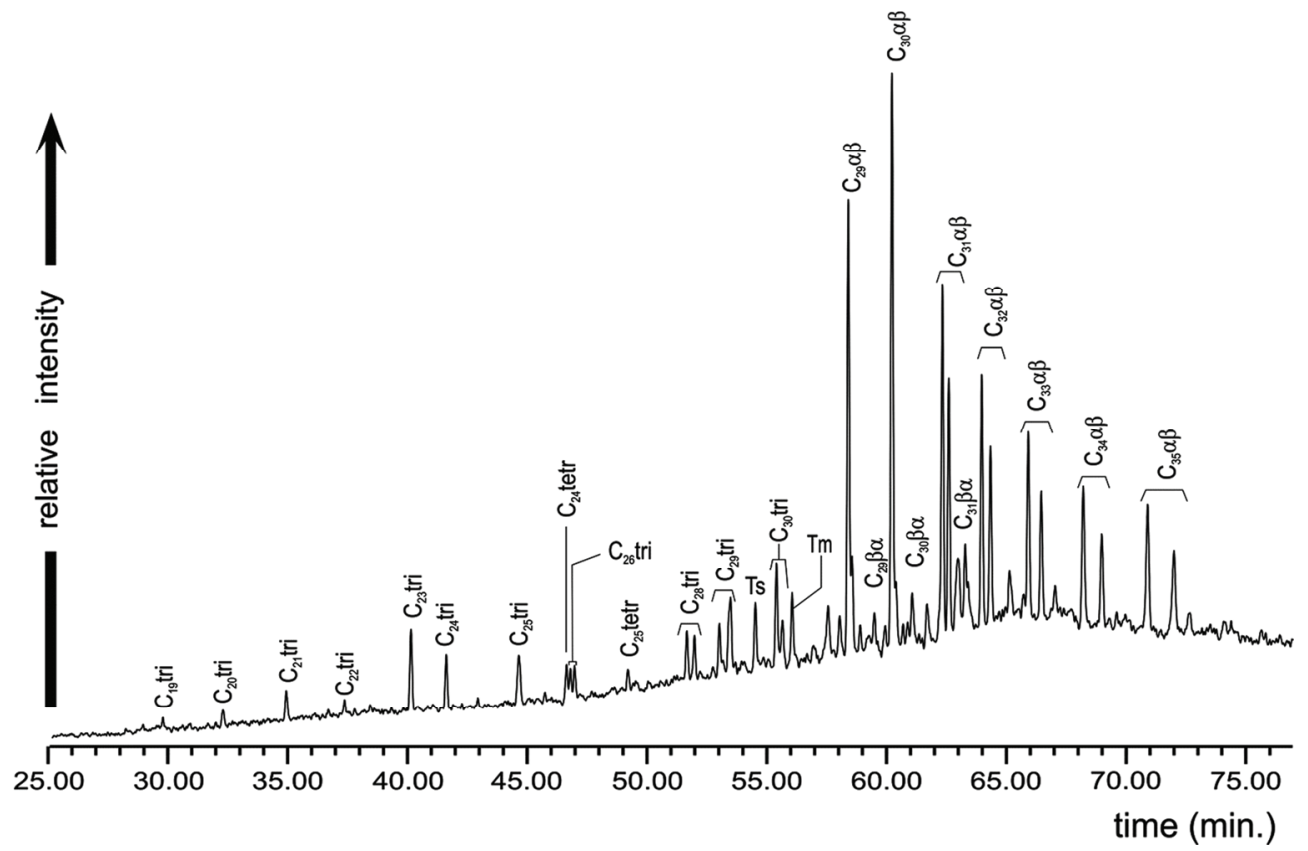

Fig. 3. Distribution of tri- and tetracyclic triterpanes and pentacyclic triterpanes $(\mathrm{m} / \mathrm{z}=191)$ in the extract from the sludge sample D; Ts - 18 $\alpha(\mathrm{H})-22,29,30$-trisnorneohopane, Tm - 17 $\alpha(\mathrm{H})-22,29,30$ trisnorhopane, $C_{x}$ tri - tricyclic triterpane, $C_{x}$ tetr - tetracyclic triterpane, $C_{29} \alpha \beta-17 \alpha(\mathrm{H}), 21 \beta(\mathrm{H})-$ norhopane, $\quad \mathrm{C}_{29} \beta \alpha-17 \beta(\mathrm{H}), 21 \alpha(\mathrm{H})$-norhopane, $\mathrm{C}_{30} \alpha \beta-17 \alpha \quad(\mathrm{H}), 21 \beta(\mathrm{H})$-hopane, $\mathrm{C}_{30} \beta \alpha-$ $17 \beta(\mathrm{H}), 21 \beta(\mathrm{H})$-hopane, $\mathrm{C}_{31} \alpha \beta-17 \alpha(\mathrm{H}), 21 \beta(\mathrm{H})$-homohopane, $\mathrm{C}_{31} \beta \alpha-17 \beta(\mathrm{H}), 21 \alpha(\mathrm{H})$-homohopane, $\mathrm{C}_{32} \alpha \beta-17 \alpha(\mathrm{H}), 21 \beta(\mathrm{H})$-bishopane; $\mathrm{C}_{33} \alpha \beta-17 \alpha(\mathrm{H}), 21 \beta(\mathrm{H})$-trishopane; $\mathrm{C}_{34} \alpha \beta-17 \alpha(\mathrm{H}), 21 \beta(\mathrm{H})$ tetrakishopane; $\mathrm{C}_{35} \alpha \beta-17 \alpha(\mathrm{H}), 21 \beta(\mathrm{H})$-pentakishopane.

\subsubsection{Aromatic hydrocarbons}

Alkylbenzenes and polycyclic aromatic hydrocarbons such as phenanthrene $(\mathrm{m} / \mathrm{z}=178)$, fluorene, pyrene $(m / z=202)$, benzo $(a)$ anthracene, chrysene $(m / z=228)$, benzofluoranthene, benzo $(a)$ pyrene, benzo $(e)$ pyrene and perylene $(m / z=252)$, indeno[1,2,3$c, d]$ pyrene and benzo(ghi)perylene $(\mathrm{m} / \mathrm{z}=276)$ occur in the extracts in much smaller amounts than aliphatic hydrocarbons (Fig. 4). PAHs are accompanied by their alkyl derivatives such as methylphenanthrenes $(\mathrm{m} / \mathrm{z}=192)$ and dimethylphenanthrenes $(\mathrm{m} / \mathrm{z}=$ 206). However, apart from trimethylnaphthalenes $(\mathrm{m} / \mathrm{z}=170)$, their contents were too low 
to identify particular isomers. Alkylbenzenes $(\mathrm{m} / \mathrm{z}=91)$ comprise compounds such as 1-pentylheptylbenzene, 1-propylnonylbenzene and 1-butylheptylbenzene.

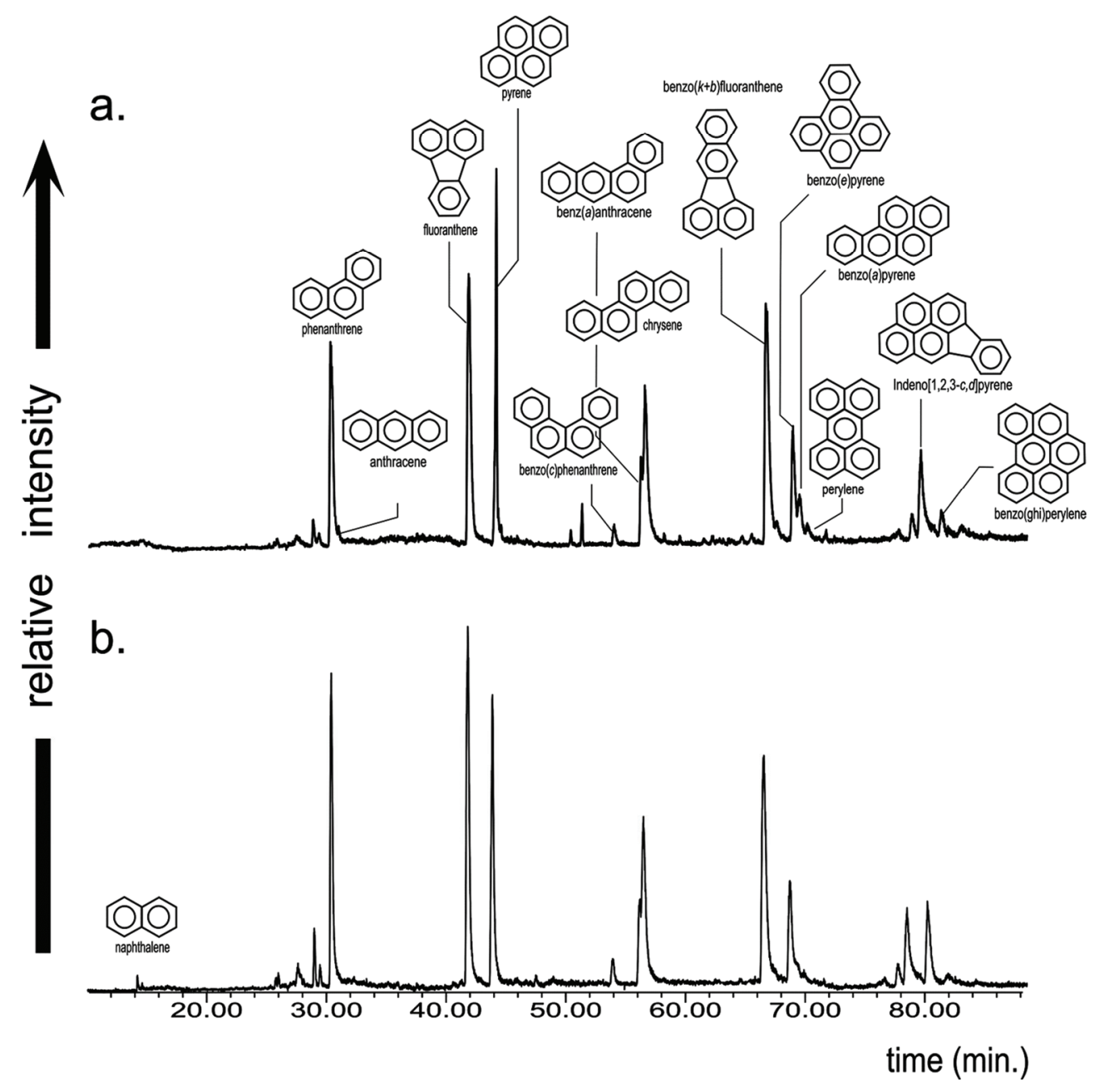

Fig. 4. Distribution of polycyclic aromatic hydrocarbons in the extract from the sludge sample 1 $(\mathrm{m} / \mathrm{z}=128+178+202+228+252+276)$, a. the sludge sample 2, b. the sludge sample 1 .

\subsubsection{Polar compounds}

In the aromatic fractions of the samples, saturated series of fatty acids, unsaturated fatty acids with a single double bond, and their esters were also identified. Figure 5 shows the distribution of commonly present methyl esters of these acids. Four methyl esters of phenyl alkyl acids $(m / z=91)$ were also identified, i.e. 9-phenylnonanoic acid, 10-phenyldecanoic acid, 11-phenylundecanoic acid and 12-phenyldodecanoic acid. Sulphur heterocyclic compounds such dibenzothiophene derivatives do not occur. 


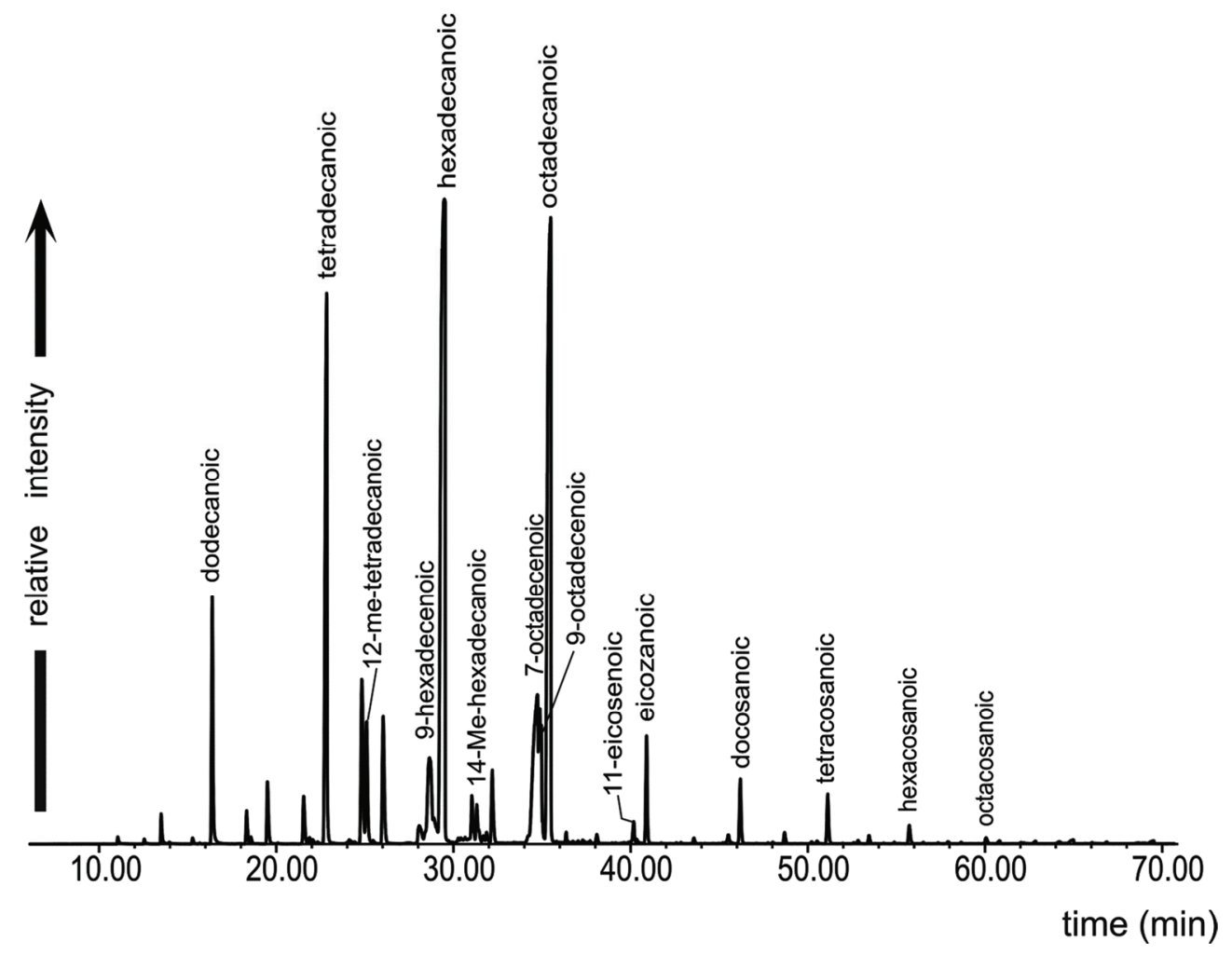

Fig. 5. Distribution of methyl esters of saturated and unsaturated fatty acids $(\mathrm{m} / \mathrm{z}=74)$, (the sludge sample 1); names of parent acids above peaks.

\section{Discussion}

\subsection{Sources of the main contaminants in the wastes}

Organic material present in urban sludge is a complex mixture of organic compounds of various origins (Eriksson et al. 2008). Based on the GC-MS analyses, it is evident that there are two main sources of compounds found in wastewaters investigated: petroleumderived material of an unspecified origin characterized below, and biological organic wastes, most probably from domestic sources. Such compounds as $n$-alkanes, pentacyclic triterpanes, and steranes can be attributed to the first source, whereas most of polar compounds such as fatty acids and their esters to the second one. Aromatic compounds (PAHs) can come from petroleum or any source related to fuel combustion.

\subsection{Geochemical features of petroleum material present in sludge extracts}

Based on the results of the distributions of biomarkers and their parameters investigation, it was found that the dominant component of organic matter in sluges was petroleum material of an unspecified origin. Urban sludge often contains degraded remains 
of various crude oil products, such as diesel oil or gasoline (e.g. Durand et al. 2004; Marchal et al. 2003). However, in the Siemianowice Śląskie material, geochemical features indicate that its most likely source was crude oil (or its products) of medium thermal maturity, as evidenced by the Carbon Preference Index (CPI) values close to the 1.60 (Table 1). CPI values are applied to express predominance of odd-over-even carbon atom $\mathrm{n}$-alkanes in distribution. With increasing maturity its values tend to decrease to 1.0 . CPI values for sludge n-alkanes suggest at least a catagenic stage of thermal evolution (corresponding to vitrinite reflectance Ro $=0.6-0.7 \%$, Tissot, Welte 1984), and input of vascular plant material to the kerogen being the source of the polluting crude oil (Bray, Evans 1961; Eglinton, Hamilton 1967; Barthlott et al. 1998). However, n-alkanes are ubiquitous compounds in any geochemical material and additional sources such as soil, coal or recent vegetation cannot be excluded. n-Alkanes present in the sludge show a dominance of odd-carbon-number n-alkane; their input could increase CPI values. Since values of hopane ratios and TNR-1 (Trimethylnaphthalene Ratio) indicate higher thermal maturity (Ro $=0.7-0.8 \%)$ than that suggested by CPI values, it is possible that the input of compounds from recent sources affected their distribution.

Pentacyclic triterpanes also show the distribution type of advanced thermal maturity, with dominating $17 \alpha(\mathrm{H}), 21 \beta(\mathrm{H})$ hopane diastereomers (abbrev. $\alpha \beta$ ), moretanes $(17 \beta(\mathrm{H}), 21 \alpha(\mathrm{H})$ hopanes, abbrev. $\beta \alpha)$ occurring only in low quantities in the extracts, and with $\beta \beta$ hopanes (biological configuration) being absent (Fig. 3). In all extracts, the values of the ratio of $\mathrm{C}_{31} \alpha \beta$ hopane diastereomers: $17 \alpha(\mathrm{H}), 21 \beta(\mathrm{H})$-29-homohopane $22 \mathrm{~S} /(17 \alpha(\mathrm{H}), 21 \beta(\mathrm{H})-29$-homohopane $22 \mathrm{~S}+17 \alpha(\mathrm{H}), 21 \beta(\mathrm{H})-29$-homohopane $22 \mathrm{R})$ are close to 0.60 ; its validity limit. The presence of hopanes with longer side-chain $\left(\mathrm{C}_{35}\right.$ and $\left.\mathrm{C}_{34}\right)$ indicates petroleum rather than coal-related organic matter as the source since hopane distributions in coal extracts contain only hopanes up to $C_{33}$ hopane (Peters et al. 2005). The absence of diterpenoids in the sludge samples also is significant as diterpenoids are the main component of matter derived from terrestrial plants (conifers) and are common in the extracts of lignites, bituminous coals and other organic matter of terrestrial origin (Noble et al. 1986; Otto, Wilde 2001).

As the values of the $\mathrm{Pr} / \mathrm{Ph}$ ratio are less than 1.0, it might be assumed that the kerogen which is the source of the contaminating crude oil in the sludge originated in an anaerobic environment (see Didyk et al. 1978). However, it is also possible that crude oil was subjected to biological degradation in the wastewater treatment process (Marchal et al. 2003). This can be supported by the values of the pristane to $n$-heptadecane $\left(\mathrm{Pr} / n-\mathrm{C}_{17}\right)$ and phytane to $n$-octadecane $\left(\mathrm{Ph} / n-\mathrm{C}_{18}\right)$ ratios which only slightly exceed 1.0 (Table 1$)$. Wang and Fingas (1999) described such a trend in surface oil spills. The distribution of lighter $n$-alkanes in the range from $n-\mathrm{C}_{13}$ to $n-\mathrm{C}_{20}$ was also affected by degradation and shows a peak envelope with a cut out shape (Fig. 1). The removal of lighter $n$-alkanes resulted in high values of $\Sigma 2 / \Sigma 1$ ratio (long-chain to short-chain $n$-alkanes, Table 1), a feature typical of slightly biodegraded or water-washed crude oils (Fig. 1; Palmer 1993). The influence of degradation is confirmed by a plot of $\mathrm{Pr} / n-\mathrm{C}_{17}$ versus $\mathrm{Ph} / n-\mathrm{C}_{18}$ (Fig. 6); all samples lie in the area corresponding to the estuarine/deltaic/fluvial/lacustrine environment of deposition. However, they show a linear trend probably due to the preferential removal of $n$-alkanes over pristane and phytane, both pf which are more resistant to biodegradation. 


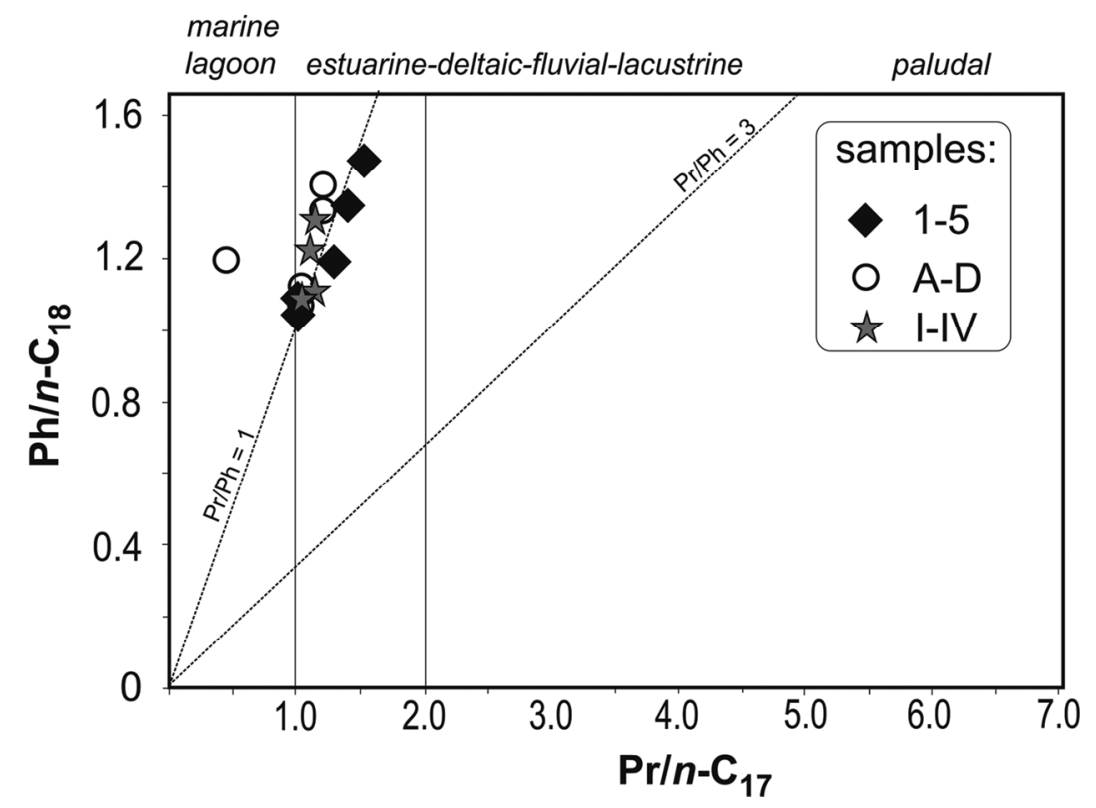

Fig. 6. The $\mathrm{Pr} / n-\mathrm{C}_{17}$ vs. $\mathrm{Ph} / n-\mathrm{C}_{18}$ diagram (after Scheffler, 2004, modified).

The type of sterane distribution with cholestane $\left(\mathrm{C}_{27}\right)$ diastereomers present in relatively high amounts compared to stigmastane diastereomers $\left(\mathrm{C}_{29}\right)$ confirms the assumption about the oil-related origin of the geochemical compounds since organic matter of the terrestrial origin (e.g. coals) usually shows sterane distributions dominated by stigmastanes (Huang, Meinschein 1979). Figure 7 shows that in the ternary plot of $C_{27}, C_{28}$ and $\mathrm{C}_{29}$ steranes, all samples fall in the range corresponding to the estuarine sedimentary environment (Huang, Meinschein 1979; Peters et al. 2005). This result agrees with that derived from the plot of $\mathrm{Pr} / n-\mathrm{C}_{17}$ versus $\mathrm{Ph} / n-\mathrm{C}_{18}$ (Fig. 6). This also suggests that the same type of petroleum contaminating the sludge or even the same crude oil. The presence of $\mathrm{C}_{30}$ steranes points to marine crude oil as a possible source of contamination, with the possible input of Chrysophyte algae (Fig. 2, 7).

Alkylbenzenes identified in sludge do not follow the distribution of $n$-alkanes as is common in sedimentary organic matter (Dong et al. 1993). Their aliphatic chains with two long branches (e.g. 1-pentylheptylbenzene) suggest an anthropogenic origin, probably alkylbenzene sulphonates commonly applied as surfactants in various detergents, emulsifiers, etc. (Oil Chem Technologies 2010; Scott, Jones 2000).

Aromatic compounds present in the samples probably come from petroleum, though some of them can be attributed to combustion or to other sources such as bituminous coals, ash from coal/biofuel combustion or coal wastes stored nearby. Unsubstituted PAHs most probably are related to crude oil, as trimethylnaphthalenes. Values of TNR-1 in the range 0.82-1.40 suggest thermally advanced maturity, at least middle catagenesis. 


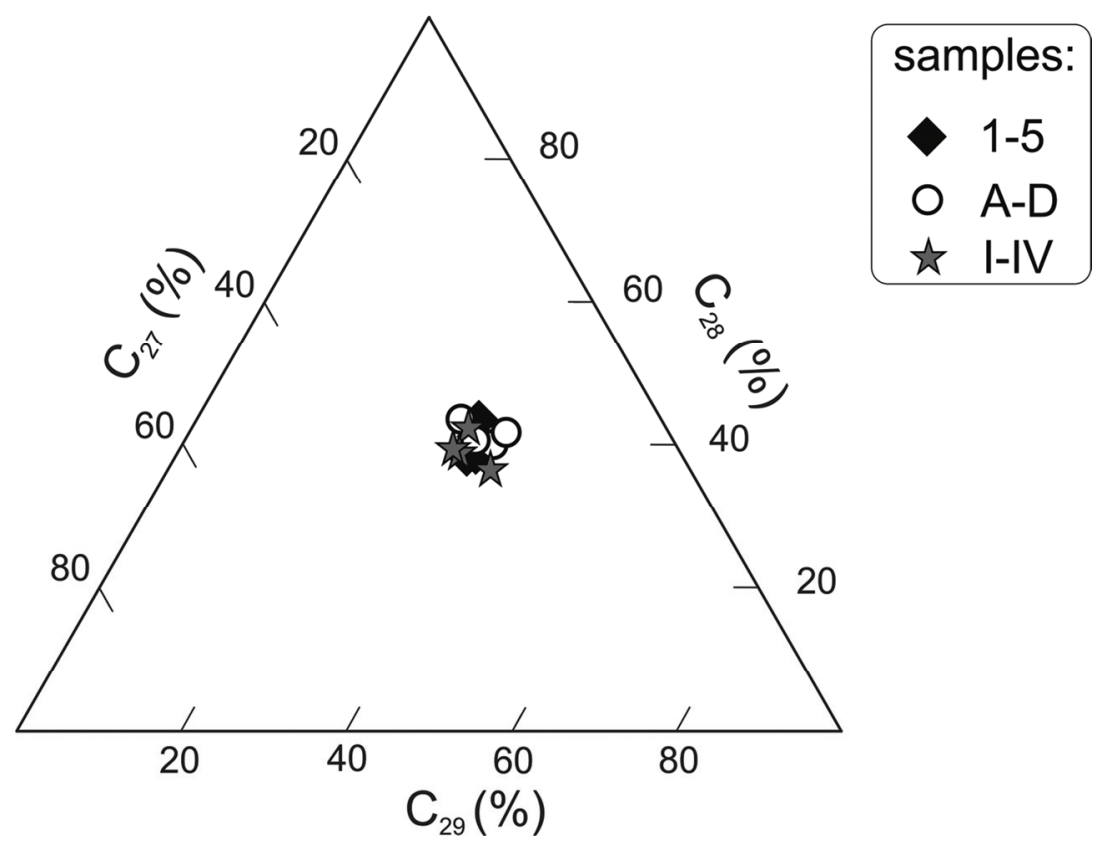

Fig. 7. Ternary diagram of the relative abundance of regular steranes $C_{27}: C_{28}: C_{29} \alpha \alpha \alpha 20 R$ (after Huang and Meinshein, 1979).

\subsection{Organic compounds related to biological wastes}

The second major source of organic compounds in the wastes is recent biological material, most probably of domestic origin. Among these compounds fatty acids dominate. They show a wide variety of structures, however most of them commonly appear in plant material, e.g. octadecanoic-, pentadecanoic- or dodecanoic acids. They can be attributed to food wastes. To the same source can be attributed esters of fatty acids and long chain aliphatic alcohols such as tetradecyl ester of dodecanoic acid, which commonly occur in cuticular waxes of vascular plants (Bray, Evans 1961; Eglington, Hamilton 1967).

One of the more interesting components identified almost in all samples is 2,6-diizopropylnaphthalene. As this compound used to inhibit the sprouting of potatoes, we presume a food source (Zhang et al. 2008; Lewis et al. 1997). However, this compounds was also found in paper package and tissues (Zhang et al. 2008). The same anthropogenic origin can be inferred for long-chain alkyl benzenes and methyl esters of phenyl alkyl acids formed in degradation of their sulphonates (Scott, Jones 2000), and galaxolide $(1,3,4,6,7,8$ hexahydro-4,6,6,7,8,8-hexamethylcyclopenta-2-benzopyran; $\mathrm{m} / \mathrm{z}=243$ ), a common musk in cleaners, detergents, soap, etc. (International Flavors \& Fragrances 2007).

\section{Conclusions}

GC-MS analyses of the waste extracts of the "Centrum" wastewater treatment plant enable the identification of several groups of organic compounds that are indicative of their 
probable sources. There are two main sources: crude oil derived material and biological organic wastes, most probably from domestic sources. Compounds such as $n$-alkanes, pentacyclic triterpanes, and steranes come from the first source, whereas most polar compounds such as fatty acids and their esters, from the second. Polycyclic aromatic compounds can be of geochemical origin (petroleum) or any source related to fuel combustion. Geochemical biomarkers such as $n$-alkanes, steranes and pentacyclic triterpanes were used to characterize organic matter of geological origin. This shows features of crude-oil related material from kerogen derived from organic matter, predominantly marine, deposited in an anaerobic environment with some input of terrestrial organic matter ( $n$-alkane distribution with odd-over-even carbon number atom predominance). There is some incongruity between CPI values that average 1.6 and the and the higher maturity indicated by values of TNR-1 and by hopane ratios (Ro $=0.7-0.8 \%)$. It can be explained by the input of $n$-alkanes from more recent sources (soil, vegetation) with odd-over even carbon atom number predominance. Domestic wastes input to the sludge are a source of polar compounds of biological and anthropogenic origin.

\section{References}

Barthlott, W., Neinhuis, C., Cutler, D., Ditsch, F., Meusel, I., Theisen, I., \& Wilhelmi, H. (1998). Classification and terminology of plants epicuticular waxes. Botanical Journal of the Linnean Society, 126, 237-260. DOI: 10.1111/j.1095-8339.1998.tb02529.x.

Berset, J.D., \& Holzer, R. (1999). Quantitative determination of polycyclic aromatic hydrocarbons, polychlorinated biphenyls and organochlorine pesticides in sewage sludges using supercritical fluid extraction and mass spectrometric detection. Journal of Chromatography A, 852, 545-558. DOI: 10.1016/S00219673(99)00641-X.

Bodzek, D., \& Janoszka, B. (1999). Comparison of polycyclic aromatic compounds and heavy metals contents in sewage sludges from industrialized and non-industrialized region. Water, Air, Soil Pollution, 111, 359-369. DOI: 10.1023/A:1005066327712.

Bray, E.E., \& Evans, E.D. (1961). Distribution of $n$-paraffin as a clue to recognition of source beds. Geochimica et Cosmochimica Acta, 22, 2-15. DOI: 10.1016/0016-7037(61)90069-2.

Didyk, B.M., Simoneit, B-T., Brassell, S.C., \& Eglinton, G. (1978). Organic geochemical indicators of paleoenvironmental conditions of sedimentation. Nature, 272, 217-222.

Dong, J-Z., Vorking, W.P., \& Lee, M.L. (1993). Origin of long-chain alkylcyclohexanes and alkylbenzenes in a coal-bed wax. Geochimica et Cosmochimica Acta, 57, 837-849.

Durand, C., Ruban, V., Ambles, A., \& Oudot, J. (2004). Characterization of the organic matter of sludge: determination of lipids, hydrocarbons and PAHs from road retention/infiltration ponds in France. Environmental Pollution, 132, 375-384. DOI: 10.1016/j.envpol.2004.05.038.

Eglinton, G., \& Hamilton, R.J. (1967). Leaf epicuticular waxes. Science, 156, 1322-1335. DOI: 10.1126/science.156.3780.1322.

Eriksson, E., Christensen, N., Schmidt, J.E., \& Ledin, A. (2008). Potential priority pollutants in sewage sludge. Desalination, 226, 371-388. DOI:10.1016/j.desal.0000.00.000.

Hartmann, L. (1996). Biologiczne oczyszczanie ścieków. Warszawa: Wydawnictwo Instalator Polski.

Huang, W.-Y., \& Meinschein, W.G. (1979). Sterols as ecological indicators. Geochimica et Cosmochimica Acta, 43, 739-745. DOI: 10.1016/0016-7037(79)90257-6.

International Flavors \& Fragrances (2007) Galaxolide $50 \quad$ DPG. 1,3,4,6,7,8-hexahydro-4,6,6,7,8,8hexamethylcyclopenta-gamma-2-benzopyran. Retrievied April 19, 2011, from http://www.iff.com/ Ingredients.nsf/0/DFED00F87A7ABAE385256D650044ECD6

Kowal, A.L. (1997). Odnowa wody: podstawy teoretyczne procesów (2nd ed., corrected). Wrocław: Oficyna Wydawnicza Politechniki Wrocławskiej. 
Lewis, M.D., Kleinkopf, G.E., \& Shetty, K.K. (1997). Dimethylnaphthalene and diisopropylnaphthalene for potato sprout control in storage: 1. Application methodology and efficacy. American Journal of Potato Research, 74, 183-197. DOI: $10.1007 / \mathrm{BF} 02851597$.

Leythauser, D., Schwartzkopf Th., (1985). The pristane/ $n$-heptadecane ratio as an indicator for recognition of hydrocarbon migration effects. Organic Geochemistry 10, 191-197. DOI: 10.1016/0146-6380(86)90022-7

Marchal, R., Penet, S., Solano-Serena, F., \& Vandecasteele, J.P. (2003). Gasoline and diesel oil biodegradation. Oil \& Gas Science and Technology - Rev. IFP 58, 441-448. DOI: 10.2516/ogst:2003027.

Miksch, K., \& Sikora, J. (2010). Biotechnologia ścieków. Warszawa : Wydawnictwo Naukowe PWN.

Noble, R.A., Aleksander, R., Kagi, R.I., \& Knox, J. (1986). Identification of some diterpenoid hydrocarbons in petroleum. Organic Chemistry 10, 825-829. DOI: 10.1016/S01 46-6380(86)80019-5.

Oil Chem Technologies (2010). Anionic surfactants. New Arylalkyl Sulfonates (AASA). Retrieved April 19, 2011, from http://www.oil-chem.com/anionic.htm

Otto, A., \& Wilde, V. (2001). Sesqui-, di-, and triterpenoids as chemosystematic markers in extant conifers: a review. Botanical Review 67, 141-238. DOI: 10.1007/BF02858076.

Palmer, S.E. (1993). Effect of Biodegradation and Water Washing on Crude Oil Composition, in Organic Geochemistry, Principles and Applications. In M.H. Engel \& S.A. Macko (Eds.), New York: Plenum Press.

Pawelczyk-Szpilowa, M. (1980). Ćwiczenia z mikrobiologii wody i ścieków. Warszawa: Wydawnictwo Naukowe PWN.

Peters, K.E., Walters, C.C., \& Moldowan, J.M. (2005). The Biomarker Guide (2nd ed.). Cambridge, Cambridge University Press.

Polski Komitet Normalizacyjny (National Standards Body in Poland). (1988). Woda i ścieki - Ogólne zasady pobierania próbek do badań fizycznych, chemicznych i biologicznych - Utrwalanie i przechowywanie próbek (Polish Standard: Water and sewage - General principles of sampling for physical, chemical and biological analyses - Sample preservation and storage). PN-C-04632-04:1988. Warszawa.

Radke, M., Welte, D.H. \& Willsch, H. (1986). Maturity parameters based on aromatic hydrocarbons: influence of organic matter type. Organic Geochemistry 10, 51-63. DOI: 10.1016/0146-6380(86)90008-2.

Scheffler, K. (2004). Reconstruction of sedimentary environment and climate conditions by multi-geochemical investigations of Late Palaeozoic glacial to postglacial sedimentary sequences from SW-Gondwana. Dissertation zur Erlangung des Doktorgrades der Mathematisch-Naturwissenschaftlichen Fakultät der Rheinischen Fredrich-Wilhelms-Univeristät, Bonn, http://deposit.ddb.de/.

Scott, M.J., \& Jones, M.N. (2000). The biodegradation of surfactants in the environment. Biochimica et Biophysica Acta, 1508, 235-251. DOI:10.1016/S0304-4157(00)00013-7.

Seifert, W.K. \& Moldowan, J.M. (1980). The effect of thermal stress on source-rock quality as measured by hopane stereochemistry. Physics and Chemistry of the Earth 12, 229-237. DOI: 10.1016/00791946(79)90107-1.

Stevens, J.L., Northcott, G.L., Stern, G.A., Tomy, T.G., \& Jones, K.C. (2003). PAHs, PCBs, PCNs Organochlorine Pesticides, Synthetic Musks, and Polychlorinated $n$-Alkanes in U.K. Sewage Sludge: Survey Results and Implications. Environment Science and Technology, 37, 462-467. DOI: 10.1021/es020161y.

Tissot, B.P., \& Welte, D.H. (1984). Petroleum formation and occurrence. Berlin: Springer-Verlag.

Wang, Z., \& Fingas, M. (1999). Oil spill identification. Journal of Chromatography A, 843, 369-441. DOI: doi:10.1016/S0021-9673(99)00120-X

Wiley, J. (2000). The Wiley/NBS Registry of Mass Spectral Data. New York: J Wiley and Sons.

Zhang, K., Noonan, G.O., \& Begley, T.H. (2008). Determination of 2,6-diisopropylnaphthalene (DIPN) and $n$-dibutylphthalate (DBP) in food and paper packaging materials from US marketplaces. Food Additives and Contaminants, 25(11), 1416-1423. DOI: 10.1080/02652030802163380. 